Received 08/10/2020 Review began $08 / 11 / 2020$ Review ended 08/22/2020 Published 08/28/2020 Corrected 10/07/2020

(c) Copyright 2020

Qureshi et al. This is an open access article distributed under the terms of the Creative Commons Attribution License CC-BY 4.0 . which permits unrestricted use, distribution, and reproduction in any medium, provided the original author and source are credited.

\section{Corrected: Limb Salvage Versus Amputation: A Review of the Current Evidence}

\author{
Mobeen K. Qureshi ${ }^{1}$, Ali Ghaffar ${ }^{1}$, Sameem Tak ${ }^{2}$, Ahmad Khaled ${ }^{1}$ \\ 1. Trauma and Orthopaedics, East Lancashire NHS Hospitals, Blackburn, GBR 2. Trauma and Orthopaedics, Kettering \\ General Hospital, Kettering, GBR
}

Corresponding author: Ali Ghaffar, dr.alighaffar@gmail.com

\section{This article has been corrected.}

Correction date: October 07, 2020. Cite this correction as Qureshi M K, Ghaffar A, Tak S, et al. (October 07, 2020) Correction: Limb Salvage Versus Amputation: A Review of the Current Evidence. Cureus 12(10): c38. doi:10.7759/cureus.c38.

During final copy editing of this article, the acronym LEAP was incorrectly expanded to "Learning Early About Peanut Allergy" instead of the correct "Lower Extremity Assessment Project" in the article abstract. Cureus sincerely regrets this error and wishes to make clear that the authors were in no way responsible for this error. The text has been corrected in the article.

\begin{abstract}
In the trauma situation where the trauma team is faced with a severely injured limb, it requires judicious thinking and evaluating not only the injury in isolation but the patient as a whole when considering the management options. The aim must be to give the best quality of life and avoid repeated admissions to hospital for associated complications in the future.
\end{abstract}

The decision to amputate or salvage a limb should be based on numerous factors, such as the patient's preinjury status, injury factors (soft tissue injury, location, contamination and physiological status), patient's wish and available resources.

The biggest challenge when faced with a complex limb injury is deciding what management route to take with a satisfactory outcome for the patient being the main goal.

Many studies have been undertaken looking at the outcome of successful limb salvage versus primary amputation. Studies such as the Lower Extremity Assessment Project (LEAP) study have concluded that there was no difference of outcome at the two-year stage between the two strategies.

Categories: Emergency Medicine, Orthopedics, Trauma

Keywords: limb salvage, amputation, trauma

\section{Introduction And Background}

In the trauma situation where the trauma team is faced with a severely injured limb, it requires judicious thinking and evaluating not only the injury in isolation but the patient as a whole when considering different management options. When considering whether to salvage a limb or to proceed with amputation, many variables must be taken into consideration; these include objective aspects, such as the injury and the comorbidities of the patient, as well the subjective aspects, such as the economic, social and psychological status. The aim must be to give the best quality of life and avoid repeated admissions to hospital for associated complications in the future. Currently, no consensus has been reached as how best to deal with these situations, as there have been few high-level studies.

\section{Decision-making factors}

The decision to amputate or salvage a limb should be based on numerous factors, such as the patient's preinjury status, injury factors such as soft tissue injury, location, contamination and physiological status, patient's wishes and availability of resources [1].

The strategy of treatment options is based on the type of fracture and associated soft tissue damage, the duration of the warm ischaemic period and the overall condition of the patient [2]. In the case of polytrauma patients and in those who are in a critical condition physiologically, limb salvage may be contraindicated, as the priority is to preserve life [3]. In patients who are stable but have a severely injured limb, the decision for limb salvage or amputation primarily depends on the level of soft tissue injury sustained, as well as 
neurovascular damage impacting the long-term outcomes. When considering the vascular status, it has been shown that a warm ischaemia time of greater than six hours greatly reduces the success rate of a salvage procedure [4]. However, this can be improved if the limb is in ice-cold water for four to eight hours, giving a window of up to eight hours to perform a salvage procedure [5]. In those with a nerve injury, some studies have favoured amputation such as for a Gustilo type IIIC fracture with associated nerve injury [6]. Another study recommended amputation for patients with posterior tibial nerve impairment [4]. For injuries with soft tissue involvement, the key factor that will determine a good outcome is the coverage with an adequate blood supply, which will prevent the risk of infections and non-union. Another determinant is adequate debridement of necrotic tissue.

Another consideration is the level of amputation. The goal is to preserve as much of the limb as possible. Using the lower limb as an example, a long limb uses less energy when walking; therefore, a below-knee amputation is preferable to through-the-knee and above-knee amputations [7].

The wish of the patient should also be considered when making a decision. Some patients may not be able to afford a protracted absence from employment and therefore may decide to have an amputation. Other personal factors include social support, availability of rehabilitation services and the willingness to engage with such services.

Depending on the medical system within which a patient is treated, the financial cost may dictate the decision-making process. The decision to salvage a limb that eventually leads to amputation will be a costlier decision. Goldberg et al. calculated the cost of hospitalization per patient to be $\$ 18,698$, of which patients paid \$2,261 on average in the United States of America [8]. Clearly a burden on low income individuals and their family. However, another study has concluded that amputation is costlier than limb salvage. Chung et al. stated that an amputation for a 40-year-old patient will cost at least \$93,606 and up to $\$ 154,636$ more than limb salvage (independent of ongoing prosthesis needs) [9]. In a state-funded healthcare system, the financial aspect would not have impact on the patient directly.

It has also been shown that delayed amputation carries an increased risk of sepsis and infective complication as compared to primary amputation [10].

A multitude of scoring systems have been developed to aid the surgeon when evaluating the severity of an injured limb. These include the Mangled Extremity Severity Index (MESI) devised by Gregory et al., which is further developed by McNamara et al. into the Nerve injury, Ischemia, Soft-tissue contamination, Skeletal injury, Shock and Age (NISSA) score, Hanover Fracture Scale (HFS) and the Limb Salvage Index (LSI) $[6,11$ 13]. However, these scoring systems have been shown to be imprecise when prospectively making a clinical decision whether to amputate or salvage a limb [14-16]. This is mainly thought to be due to the scores being devised from retrospective studies, as well as other factors such as differences in an interobserver grouping of the severely injured limb.

A recent retrospective study carried out looked at 1,354 patients with mangled lower extremities who were treated at 222 level I and II trauma centres. Only $21 \%$ of patients underwent amputation, with half of these amputations occurring within 24 hours of the injury. Amputation was most likely in those with certain types of injury, high energy impact, associated injures such as severe head injury and hypotension [17]. This study suggests that the majority of injured limbs are being salvaged and that amputation only occurs in the immediate period, most likely due to the inevitability that an amputation will occur at some stage.

\section{Review \\ Outcomes}

The biggest challenge when faced with a complex limb injury is deciding what management route to take with a satisfactory outcome for the patient being the main goal. As a consequence, the medical team has to consider different factors, such as the long-term psychological impact, functional and quality of life (QoL) outcomes. There has been much debate on how to define and measure QoL [18]. However, a consensus points to a range of domains, such as physical, psychological and social.

Patient factors also dictate the outcome and therefore together with physical, social and psychological domains, economic status must be considered. Francel reported that patient factors rather than the severity of the injury correlated with a successful return to work. Patients who were younger than 40 years, more educated and in white-collar employment tended to fare better [19].

In 2006, Barros et al. published “The Belfast Approach,” which advocates the early placement of shunts in both artery and vein, with the aim of reconstruction of all injured anatomical structures on the first encounter. They state that the shunt ultimately buy time for meticulous care, significantly reducing fasciotomies and resulting in a significant reduction in the incidence of contracture and amputation. They also championed the case for optimal vein reconstruction. This strategy was shown to reduce the incidence of re-exploration and secondary repair [20]. 
Hoogendoorn and van der Werken looked at grade III open tibial fractures and the functional outcome and QoL in amputees versus patients with successful reconstruction. They concluded that patients with successful reconstruction experience significantly more complications, requiring further surgical interventions, as compared to those who underwent primary amputation. The complications related to the former group were due to problems in bone healing [21].

This is countered by Dagum et al. who have reported that patients who underwent amputation had lower physical functional outcome scores compared to those who had successful limb salvage procedures [22]. In another study, Puno et al. reported no difference in function and pain between primary amputation and limb salvage [23].

According to MacKenzie et al., predictors of poor outcomes include rehospitalizations for a major complication, non-white race, lower socioeconomic status, low self-efficacy, smoking and involvement in disability compensation litigation [24]. These findings are difficult to implement and consider when making a clinical decision.

The highest level of evidence available was conducted by Bosse et al. and was named the Learning Early About Peanut Allergy (LEAP) study. It was a multicentre prospective cohort study including 601 patients enrolled from eight level I trauma centres in the United States of America who had sustained high-energy lower limb injuries. The primary outcome of the study was derived using a self-reported measure of health status that was called the Sickness Impact Profile (SIP), which was measured for several months after the injury. Scored ranged from 0 to 100 with a score $>10$ considered to represent severe disability [25]. The conclusion reached by the study was that at the two-year follow-up point there was no difference in the health status between those who had undergone amputation compared to those who had had their limb salvaged. It was noted however that those who underwent amputation were less likely to require rehospitalizations.

A meta-analysis was conducted by the Evidence-Based Orthopaedic Trauma Working Group in 2007 that also supported the LEAP study by concluding that there was no significant difference of functional outcome in those treated with either an amputation or successful limb salvage, at least up to seven years post-injury [26].

Another meta-analysis published in 2011 by Akula et al. concluded that lower limb reconstruction is more acceptable psychologically to patients with severe lower limb trauma compared to amputation; however, physical outcomes for both management strategies were similar [27].

In military studies, from the experience in Afghanistan and Iraq, data have been utilized from the Expeditionary Medical Encounter Database. In a retrospective study from 2001 to 2008, there were a total of 587 early amputees and $117 \mathrm{limb}$ salvage patients. It was shown that early amputees had similar physical outcomes but were noted to have a lower rate of psychological disorders [28].

\section{Conclusions}

The decision to either amputate or salvage a limb is a complex one. There is a multitude of factors that dictate not only the decision but also the outcome. When looking at the decision-making progress, different aspects such as environmental factors will influence which route to take. There will inevitably be a difference depending on the location of the patient. If they live in an area that has no established trauma network or in a rural area that does, then the availability of specialists will dictate the decision. The status of a patient is also crucial, as in the case of a polytrauma patient who is critical, the main goal would be to preserve life and not necessarily save the limb. In patients who are fortunate to be bought to a trauma centre with all the available specialists, then a multidisciplinary approach must be taken. When making a decision, if possible the patient must be involved in the process. In private healthcare systems, the financial burden for the patient and immediate family may influence what can and cannot be done.

As has been shown many studies have been undertaken looking at the outcome of successful limb salvage versus primary amputation. A consensus has not been reached and many studies argue one strategy over the other; however, the higher level of evidence has become available over the last decade including the LEAP study, which concluded that there was no difference at the two-year stage between the two strategies. Two meta-analyses have given similar conclusions, with reconstructive surgery being suggested as the better strategy based only on better psychological outcomes. This does come at a risk of greater rehospitalizations. This all leads to the crucial step of involving the patient in the decision process. This in itself can be challenging as in the critical period post trauma, a patient may not be able to communicate or be able to give an informed decision.

\section{Additional Information}

\section{Disclosures}

Conflicts of interest: In compliance with the ICMJE uniform disclosure form, all authors declare the 
following: Payment/services info: All authors have declared that no financial support was received from any organization for the submitted work. Financial relationships: All authors have declared that they have no financial relationships at present or within the previous three years with any organizations that might have an interest in the submitted work. Other relationships: All authors have declared that there are no other relationships or activities that could appear to have influenced the submitted work.

\section{References}

1. Patel MB, Richter KM, Shafi S: Mangled extremity: amputation versus salvage. Curr Trauma Rep. 2015, 1:4549. 10.1007/s40719-014-0003-6

2. Schaser K-D, Melcher I, Stockle U, Bail HJ, Puhl G, Settmacher U, Haas NP: Interdisciplinarity in reconstructive surgery of the extremities. (Article in German). Unfallchirurg. 2004, 107:732-743.

3. Markgraf E, Böhm B, Bartel M, Dorow C, Rimpler H, Friedel R: Traumatic peripheral vascular injuries. Unfallchirurg. 1998, 101:508-519. 10.1007/s001130050303

4. Lange RH, Bach AW, Hansen ST Jr, Johansen KH: Open tibial fractures with associated vascular injuries: prognosis for limb salvage. J Trauma. 1985, 25:203-208. 10.1097/00005373-198503000-00006

5. Märdian S, Schaser KD, Wichlas F, Jakobs C, Kraphol B, Schwabe P: Lower limb salvage: Indication and decision making for replantation, revascularisation and amputation. Acta Chir Orthop Traumatol Cech. 2014, 81:9-21.

6. Russell WL, Sailors DM, Whittle TB, Fisher DF, Burns RP: Limb salvage versus traumatic amputation. A decision based on a seven-part predictive index. Ann Surg. 1991, 213:473-480. 10.1097/00000658199105000-00013

7. Bell JC, Wolf EJ, Schnall BL, Tis JE, Potter BK: Transfemoral amputations: is there an effect of residual limb length and orientation on energy expenditure?. Clin Orthop Relat Res. 2014, 472:3055-3061. 10.1007/s11999-014-3630-X

8. Goldberg BA, Mootha RK, Lindsey RW: Train accidents involving pedestrians, motor vehicles, and motorcycles. Am J Orthop (Belle Mead NJ). 1998, 27:315-320.

9. Chung KC, Saddawi-Konefka D, Haase SC, Kaul G: A cost-utility analysis of amputation versus salvage for gustilo type IIIB and IIIC open tibial fractures. Plast Reconstr Surg. 2009, 124:1965-1973. 10.1097/PRS.0b013e3181bcf156

10. Bondurant FJ, Cotler HB, Buckle R, Miller-Crotchett P, Browner BD: The medical and economic impact of severely injured lower extremities. J Trauma. 1988, 28:1270-1273. 10.1097/00005373-198808000-00023

11. Gregory RT, Gould RJ, Peclet M, et al.: The mangled extremity syndrome (M.E.S.): a severity grading system for multisystem injury of the extremity. J Trauma. 1985, 25:1147-1150.

12. McNamara MG, Heckman JD, Corley FG: Severe open fractures of the lower extremity: a retrospective evaluation of the Mangled Extremity Severity Score (MESS). J Orthop Trauma. 1994, 8:81-87.

13. Tscherne H, Oestern HJ: A new classification of soft-tissue damage in open and closed fractures (author's transl). (Article in German). Unfallheilkunde. 1982, 85:111-115.

14. Bosse MJ, MacKenzie EJ, Kellam JF, et al.: A prospective evaluation of the clinical utility of the lowerextremity injury-severity scores. J Bone Joint Surg Am. 2001, 83:3-14. 10.2106/00004623-200101000-00002

15. Behdad S, Rafiei M, Taheri H, Behdad S, Mohammadzadeh M, Kiani G, Hosseinpour M: Evaluation of Mangled Extremity Severity Score (MESS) as a predictor of lower limb amputation in children with trauma. Eur J Pediatr Surg. 2012, 22:465-469. 10.1055/s-0032-1322541

16. Stewart DA, Coombs CJ, Graham HK: Application of lower extremity injury severity scores in children . J Child Orthop. 2012, 6:427-431.

17. De Mestral C, Sharma S, Haas B, Gomez D, Nathens AB: A contemporary analysis of the management of the mangled lower extremity. J Trauma Acute Care Surg. 2013, 74:597-603. 10.1097/TA.0b013e31827a05e3

18. Leplege A, Hunt S: The problem of quality of life in medicine . JAMA. 1997, 278:47-50. 10.1001/jama.1997.03550010061041

19. Francel TJ: Improving reemployment rates after limb salvage of acute severe tibial fractures by microvascular soft-tissue reconstruction. Plast Reconstr Surg. 1994, 93:1028-1034.

20. Barros D'Sa AA, Harkin DW, Blair PH, Hood JM, McIlrath E: The Belfast approach to managing complex lower limb vascular injuries. Eur J Vasc Endovasc Surg. 2006, 32:246-256. 10.1016/j.ejvs.2006.02.004

21. Hoogendoorn JM, van der Werken C: Grade III open tibial fractures. Functional outcome and quality of life in amputees versus patients with successful reconstruction. Injury. 2001, 32:329-334. 10.1016/s00201383(00)00250-3

22. Dagum AB, Best AK, Schemitsch EH, Mahoney JL, Mahomed MN, Blight KR: Salvage after severe lowerextremity trauma: are the outcomes worth the means?. Plast Reconstr Surg. 1999, 103:1212-1220. 10.1097/00006534-199904040-00017

23. Puno RM, Grossfeld SL, Henry SL, Seligson D, Harkess J, Tsai TM: Functional outcome of patients with salvageable limbs with grades III-B and III-C open fractures of the tibia. Microsurgery. 1996, 1996:167-173.

24. MacKenzie EJ, Bosse MJ, Pollak AN, et al.: Long-term persistence of disability following severe lower-limb trauma: results of a seven-year follow-up. J Bone Joint Surg Am. 2005, 87:1801-1809.

25. Bosse MJ, MacKenzie EJ, Kellam JF, et al.: An analysis of outcomes of reconstruction or amputation after leg-threatening injuries. N Engl J Med. 2002, 347:1924-1931.

26. Busse JW, Jacobs CL, Swiontkowski MF, Bosse MJ, Bhandari M, Evidence-Based Orthopaedic Trauma Working Group: Complex limb salvage or early amputation for severe lower-limb injury: a meta-analysis of observational studies. J Orthop Trauma. 2007, 21:70-76. 10.1097/BOT.0b013e31802cbc43

27. Akula M, Gella S, Shaw CJ, McShane P, Mohsen AM: A meta-analysis of amputation versus limb salvage in mangled lower limb injuries: the patient perspective. Injury. 2011, 42:1194-1197. 10.1016/j.injury.2010.05.003

28. Melcer T, Sechriest VF, Walker J, Galarneau M: A comparison of health outcomes for combat amputee and limb salvage patients injured in Iraq and Afghanistan wars. J Trauma Acute Care Surg. 2013, 75:S247-S254. 10.1097/TA.0b013e318299d95e 